\title{
Art, Human Condition and Beyond ...
}

\author{
Rena Thapa \\ Lalitkala Campus, Tribhuvan University, Bhotahity, Kathmandu, Nepal
}

Received: $\mathrm{Feb} 7,2019$

Revised: April 22, 2019

Accepted: April 25, 2019

\begin{abstract}
Philosophers of different ages have made rigorous attempts to define art aiming to establish a set of characteristics applicable to all kinds of fine arts. However to point a definite meaning of art is elusive task. Similarly the question whether art can be didactic to provide knowledge, or insight is as old as philosophy itself. Art can be appreciated, enjoyed and loved for the powerful emotional values it reflects to the beholders. The production of art deals with creativity, imagination and innate ability of an artist. Art evolves from the culture that inspires artistic expression and art is born from the inner necessity of the artist. To determine the coherent ontological status of works of art has been a problematic issue despite the consistent philosophical practices. The metaphysical categorization of art as "the imaginary experience of the total activity" of the artist recreated by competent viewer is not all inclusive perception of art. The more liberal outlook of art as abstract cultural entities that are created at certain time through human activities seems convincing and relevant.
\end{abstract}

Keywords: Abstracta, metaphysics, ontology, aesthetics, spatio-temporal, postmodern

\section{Introduction}

Art is the way things, ideas, are expressed. It is how the media is used to communicate intimate concepts sharing the way one experiences the world; it is the extension of personality. Beauty in art is not just the decoration and cosmetics. It's the measure of its effect, emotions and it's the gauge of successful communication. Beauty in art is in fact the response of beholders. Critics believe when art successfully conveys artists' most profound intended emotions, the desired concepts, whether pretty and bright, or dark or sinister then it is considered beautiful. However, the successful communication is a farfetched ambition because beauty in art is eternally subjective. Aesthetic responses are not often guided by artist's intentions. The work of art is rather evaluated as higher and lower, popular or ridiculous, significant or trivial in terms of cultural context. And the measures of these evaluations are determined by senses aroused (hope, despair, cynicism, wonder, adoration or spite) on audience, a cultural construct, by particular art. Whatever artists create has link with humanity, human conditions. That is why art can communicate beyond language and time, appealing to our common humanity and linking disparate communities, intelligence and experience. A fundamental purpose inherent to most artistic discipline is the underlying intention to appeal to, and connect with human emotion. In its broadest form art is the exploration of human condition, a product of the human experience leading to utilitarian, decorative, therapeutic, communicative, intellectual end and beyond. 


\section{Art and Human Condition}

Human nature takes shapes in myriad ways. Longren recognizes the essential foundation of human nature conditioned by historical situatedness and the contingency upon the universal seeing the relationship as "human nature and historicity" [3]. Human life, on the other hand is a journey characterized by curiosity, isolation, satisfaction, pangs of grief, love, joy, the search for gratification and the awareness and inescapability of death; a journey each human undertakes, following a universal path, fulfilling the human experience, an extremely personal yet universal concept. Wallace views that human unity is based upon the primacy of the spiritual and incorruptible nature of the soul, without losing sight of the need for human community and fellowship that assist the actualization and the manifestation of the powers of the soul [8]. Human persons are a unity of spirit and flesh, a unity that is grounded in the materiality and the immateriality of the created order. In general terms this traditional approach would see cultures and civilizations as the manifested fruit of the relationship between the universal nature that human beings share and the particularity of the manifestations of this nature as evidenced in local cultures and civilizations. Human nature is an essence, as seeds sown deep in the human person that germinate and flourish as the result of the powers of soul; the imagination, the intellect, and the will, as well as moral, social, ethical, religious, and intellectual influences. However beneath everyone's outer shell, are the same feelings, the same experiences, and the same yearnings. The art work ignites a feeling of togetherness and connectedness and of empathy.

Each human being considers oneself starkly different from every other person. The feeling of empathy connects one with the other. The art has the power to make audience feel understood, as a part of them has been looked into and exposed, by exposing part of another and allowing them to relate. These parts of a person and the matters of human conditions have existed for as long as humans have existed. However increasing technologies and industrialization has altered the human experience with values of materialistic goods and technical apparatus. When such possessions are stripped away, we are left again with the blank slate of the self, the existential, emotional and integral human- a relative state shared by all. Art delves into exploration of tangible, as human being itself and of intangible like sensation and emotion. Ideas, images, shapes, colors, symbols perfectioned by artist in art allow the audience to relate, see, place and differentiate themselves in. The intangible emotions and sensations are explored through visual, verbal or audio art such as colors, images, words, music etc. Art can explore images, real places and settings, or any sort of emotional situations that can trigger emotions and memories relative to human experiences [6]. Artist might make choice in style, figures, shapes, experimentation with colors, approaches employing individual insight to convey and reflect upon human experience and contemporary human condition.

\section{Art and Culture}

Culture embeds art and art offers insights into a culture's worldview. Culture is the totality of socially transmitted behavior patterns; the body of signs, symbols, literature, music, art, architecture, religion, and broadly whole array of human way of living and believing. Cultural theories have accommodated expanded understanding and inclusive perspectives widening the discussion of culture with almost borderless quality. Culture houses many facets of human spirits and aspirations irrespective of social and geographical location. Art and culture at their very core serve as some of the most significant, dynamic, participation, and social influences of human behavior and 
interaction. When put together, they have the ability to generate empathy, stir up dialogue, induce reflection and charter new relationships and ideas. Art gives clues to gender, kinship, religious faith, myth, political ideas and historical memories.

Art speaks of the drive of civilization, both supporting the establishment and also preventing subversive voices from being muted. Art leads, mirrors, rebels and reveals change in politics and morality. The outpouring of thought, ideas and discourse stream from art. Leo Tolstoy's What is Art? is a treatise concerning the nature and purpose of art, describing how art can express moral values. Tolstoy does not define art in terms of its ability to express form and beauty, but instead defines art in terms of its ability to communicate concepts of morality. For Tolstoy, aesthetic values are defined by moral values. Tolstoy believes that art is good if it is judged to be good by the majority of people. Indeed, he claims that a great work of art is only great if it can be understood by everyone [7]. Art provides a commanding and democratic way of sharing, shaping, and expressing human values. It allows humans to explore inner capabilities and gives insight on how one imagines and uses different means to relate with each other. Art and culture also provide us with a way to create useful and meaningful things whilst increasing the value of our livelihoods and firms that are driven by much more than profit margins.

\section{Ontology of Art}

Metaphysics believes universal intelligence, being the creator of all things which is known to be an ultimate unity that is "God". At the core of everything is the dazzling mystery of its being, the dynamism that keeps it in existence. Likewise art reveals the splendor, the superabundance of being, the mysterious gushing forth of the act of existing. This context raises the question whether art is as real as anything else. The ontology of art has been the central question that includes whether art belongs to any one basic ontological category, or works of art has material parts or constituent, or work of art is created or discovered, or art transcends spatio-temporal properties and so on. The common sense understanding of art normally deciphers art in terms of a thing created at a certain time, in particular cultural and historical context streaming from artist's imaginative and creative effort.

The obvious view of the ontology of art is that works of art are just physical objects- stomp of tree, pigment-covered canvases, and sequence of sound or marks on pages. However that works of art may not all be the same ontological type. Particularly concrete works of art like painting and non-cast sculpture may differ from works of music and literature. Wollheim regards simple physical-object hypothesis on the ontology of art as the real physical objects like sticks, stones and water [9]. However many other thinkers deny this hypothesis reflecting more on the imaginative aspect while creating art which is more unlike mere physical objects. R. G Collingwood contends that artist creates a work of art simply in his mind (imagination), something abstract than concrete. Even while perceiving the work of art on the part of audience, what is required is "total imaginative experience". He expresses that painted canvasses, series' of noises, or any external objects are just means that the artist provide to help the audience reconstruct for themselves the total imaginary experience the artist undergoes in creating art [1]. Jean Paul Sartre likewise argues that works of art are imaginary entities and holding an aesthetic object requires imaginative act of consciousness. However Sartre does not think works of art as imagined activities but rather unreal objects created and sustained by acts of imaginative consciousness, and existing only as long as they remain objects of such acts [5]. 
Viewing art as imaginary activities rather than as physical objects seems to make it more problematic. It has the consequence that works of art exist intermittently depending on the presence or absence of the relevant sorts of supporting mental state. Any view that identifies the work of art with pure abstract structures challenges the common concepts of art. Even the standard division of ontological categories prevalent since Plato divides art between spatio-temporally located (changing, perishable concrete object), and non-spatio- temporally located (independent, changeless, eternal abstracta) could not capture the complete feature of beliefs and practices about work of art. Work of art seems to be abstract as they continue to exist beyond particular time and place location independent of particular physical type. However the flip side is that the works of art cease to be eternal kind or Platonistic because they are cultural artifacts which come into existence at a certain time with particular historical context. They might be destroyed when if all copies, performances or memories regarding them cease to be. Moreover works of art irrespective of types and genres seem to sustain on certain human intentional states which can be identified neither with imaginary creations of individual minds or nor with physical state. They fall between the cracks of traditional category systems; temporally- determined, dependent abstracta and abstract artifacts unintervened by spatio- temporal factor. Hence the standard category bifurcation of ontology of art is non-exhaustive. The familiar systems of categories need to be broadened to include off- the track categories.

\section{Criticism of Art}

Art is a way of grasping the world; not merely the physical world as science attempts to do but the whole world, and specifically, the human world embedded, social, emotional, and spiritual experience. Art emerged around fifty thousand years back, long before cites and civilization. The wall painting that stupefied Picasso, had been carbon- dated at around seventeen hundred years old. So to define art in terms applying to both cave-dwellers and modern city sophisticates it is necessary to answer the question, "what does art do?" Art is the genre where we make meaning beyond language. Language does not abundantly function to illicit its content. Art, in part expresses ineffable, indefinable and undelineating; the experience of the audience and the intention of the artist make the meaning somehow. However it is all else multifarious and on-going.

Another essential facet is its commodification. This fact feeds the creative process that might motivate the artist to create and exchange it for monetary value. Commodification affects the artist, art critics and art connoisseur. Consequently this commodification and the closely guarded role of the art critics challenges the counter discourse and counter culture that adheres to the ideology, art cannot be sold. The stratification of art by value and the resultant counter discourse signifies the meaning of art partly. Different art trends of different epoch, such as classical, byzantine, neoclassic, modern and post modern mark the changing nature and trend of art in socio-cultural context. Shifting values are evident in varying content, forms and styles. These trends have encompassed respectively imitationalist, emotionalist, formalist and institutionalist theories of art. To point the definite meaning of art is elusive task as the word and concept of "art" is dynamic. In olden days art meant craft, something one could excel through hard work and practice. Romanticism defined art in terms of artist's originality and novelty in their subjective style. The era of modernism inspired artists to reevaluate art. Institutionalism has been the predominant notion through the later part of the twentieth century; artists, art critics, art historian, galleries and academia fundamentally make decision to consider anything a work of art. However the post modern facet has provided the vantage point to the artist to break the hegemony of institutionalism. They skip galleries and 
art world-approved realm to advertise instead. They attack the hegemony by adopting the liberal approach to capitalism, selling their object directly to private individuals. Petterson states, "We may say that artistry makes a thing more usable and useful by making it special" [4]. Art is thus, a fleeting and chimerical concept.

Postmodern thought understands human nature in term of subjectivity and the social arena is the stage upon which human nature is constructed, molded and grown. The diversity of cultural and sociological analysis has achieved newer dimension. The debate over the distinction between high and low culture has led to a more fluid notion of culture. Culture has no porous border. Culture today ranges from Mozart, Shakespeare, and renaissance paintings to tattoos, music videos, and new age spirituality. Likewise popular culture has emerged as another aspect of globalization and it depends upon the power of image. The success of popular culture is largely dependent upon the fleeting quality of images, their "here - today - gone - tomorrow" quality as well as their patchwork characteristics. According to Kandinsky art is the expression of the spiritual atmosphere of a certain period. Art evolves from the culture that inspires artistic expression. In 1912 Kandinsky argued, "Every work of art is the child of its age and, in many cases, the mother of our emotions. It follows that each period of culture produces an art of its own which can never be repeated [2]".

\section{Conclusion}

The response to art and the experience of it is considered as mystical one which serves no practical purpose in reality. However the reality may be detrimental factor for positive response to art as for each personal value may be reflected in art. Still the belief that art experience should be subjective is pervasive. Philosophers make advocacy of the typical experience of art as contemplative and disinterested, different from everyday concern. Unlike this value the social sciences such as anthropology, archeology, and sociology have assisted the aesthetics to see the art experience in terms of political, religious, social, and economic activities of a particular time and place. The later post-structuralism and post modern theory has provided multiple strategies to incorporate multiple experiences.

\section{References}

[1] Collingwood RG (1958), The Principles of Art, Oxford University Press., New York, 139-159.

[2] Kandinsky W (1912/1977), Über das Geistige in der Kunst., Insbesonderein der Malerei, Translation "Concerning the Spiritual in Art," NewYork: Dover Publications,New York, 1.

[3] Lonergan B (1974), A Second Collection, London: Darton, Longman and Todd 3-6.

[4] Pettersson R (2019), Graphic Design, Institute of Infology, Sweden: Tullinge, 42.

[5] Sartre JP (1996), The Psychology of Imagination (translated by Bernard Frechtman), Washington Square Press, New York, 246-247.

[6] Thapa GB and Thapa R (2018), The Relation of Golden Ratio, Mathematics and Aesthetics, Journal of the Institute of Engineering, 14(1): 188-199.

[7] Tolstoy LN (1960), What is Art?, translated by Almyer Maude, Mac Millan Publishing Company, New York, p. 96.

[8] Wallace AW (1977), The elements of philosophy: A compendium for philosophers and theologians, New York: Alba House.

[9] Wollheim R (1980), Art and its Objects, Second Edition, Cambridge University Press, Cambridge, 82-234. 